http://jmscr.igmpublication.org/home/ ISSN (e)-2347-176x ISSN (p) 2455-0450

crossref DOI: https://dx.doi.org/10.18535/jmscr/v7i11.21

\title{
Epidemiology and Interventions of Sickle Cell Anaemia among Children in East Madhya Pradesh
}

\author{
Authors \\ Rinku Bhagora ${ }^{1}$, Sonu Rawat ${ }^{2}$, Rakesh Singh Hazari ${ }^{3}$, Atul Mane ${ }^{4}$, Priya Kapoor ${ }^{5}$ \\ ${ }^{1}$ Assistant Professor, Department of Pathology, Government Medical College\& District hospital, Khandwa, \\ Madhya Pradesh \\ ${ }^{2}$ Demonstrator, Department of Pathology, Government Medical College\& district hospital, Khandwa, \\ Madhya Pradesh \\ ${ }^{3}$ Professor and Head, Department of Pathology, Government Medical College \& district hospital, Khandwa, \\ Madhya Pradesh \\ ${ }^{4}$ Blood bank Officer, Department of Pathology, District hospital, Khandwa, Madhya Pradesh. \\ ${ }^{5}$ Demonstrator, Department of Pathology, Government Medical College \& district hospital, Khandwa, \\ Madhya Pradesh
}

\begin{abstract}
Aims and Objectives is 1.To know the epidemiology and intervention of sickle cell anaemia.

2. Correlation of clinical findings, haematological parameters, peripheral blood picture, sickling test and HB electrophoresis.

Material and Methods: We conducted a prospective observational study of 175 cases of anaemia with SCD children to know the epidemiology of sickle cell anaemia. Data collected from case files, patient history, clinical profile, Peripheral blood findings, haematological parameters, sickling tests and HB electrophoresis reports.
\end{abstract}

Results: Prevalence of SCD in this area is $8.57 \%$. Incidence in tribal is $67 \%$. Patient ages ranged from 2 to 14 years (median 6 years) at the time of recruitment. The age at first diagnosis of SCD was 2 years in our study. 8 patients $(53.33 \%)$ were male and 7 patients (46.66 \%) were female. Maximum no. of cases present with symptoms of pallor (100\%) followed by fever (33.33\%), abdominal pain (26.66\%), chest and joint pain $(20 \%)$ \& cough \& difficulty in breathing $(20 \%)$ and skin infection (6.66\%) were found. 9 out of 15 patients (60\%) had clinically detectable splenomegaly and 4 (26.66 \%) had hepatomegaly. Severe anaemia $6.66 \%$, moderate anaemia $40 \%$ and mild anaemia $53.33 \%$ with male predominance. Laboratory parameters showed a haemolytic profile.

Conclusion: Proper and adequate counselling should be given to couple before marriage and haemoglobin genetic counselling and education should be included.

Keywords: Epidemiology, sickle cell, HB electrophoresis.

\section{Introduction}

An estimate of 250000 children are born annually with sickle cell anaemia worldwide. $75 \%-85 \%$ of the affected children are born in Africa. ${ }^{(1)}$ The coincidence of large tribal populations with the 'sickle cell belt' of Central India and northern 
Kerala and Nilgiri hills of Tamil Nadu has given assumption that tribal people are more prone to the $\mathrm{HbS}$ gene. ${ }^{(2)}$

In 1910, Dr. James Herrick, a Chicago physician, was the first American to report and identify elongated, sickle-shaped haemoglobin in an anaemic Grenadian student's blood smear. Herrick coined the now familiar term "sickle cell". (3) The disease was named "Sickle cell anaemia" by Vernon Mason in $1922 .{ }^{(4)}$ Sickle cell disease is a common hereditary hemoglobinopathy caused by a point mutation in b-globin that promotes the polymerization of deoxygenated haemoglobin, leading to red cell distortion ischemic tissue damage. ${ }^{(5)}$ Most individuals with SCD are healthy at birth and become symptomatic later in childhood after fetal haemoglobin levels decrease. ${ }^{(6)}$

Sickle cell disease is an inherited haemoglobinopathy in autosomal recessive resulting from a mutation occurs in beta-globin gene, on chromosome 11. It is includes disorders affecting the structure, function or production of haemoglobin, there is a substitution of glutamate with valine in position 6 of the beta globin resulting in the formation of haemoglobin S. The disease is expressed when Haemoglobin $S$ is inherited from both parents, the homozygous patient or HbSS suffers from sickle cell anaemia, while the heterozygous child or Haemoglobin AS is a carrier of a sickle cell trait. ${ }^{(7)}$

Sickle cell anaemia (SS): An inherited disorder of the red blood cells in which the haemoglobin is different from the normal haemoglobin. This unusual haemoglobin results in the production of unusually shaped cells and is referred to as "HbSS." Sickle cell disease (SCD): An inherited disorder of the red blood cells in which one gene is for sickle haemoglobin (S) and the other gene is for unusual haemoglobin such as S, C, and Thalassemia. Sickle cell trait: A person carrying the defective gene $\mathrm{HbS}$, but it has some normal haemoglobin $\mathrm{HbA}^{(3)}$

Sickle cell anaemia are inherited from parents as blood type, hair colour and texture, eye colour and other physical traits. The type of haemoglobin a person makes in the red blood cells depend upon what haemoglobin genes are inherited from his parents. 1. If one parent has sickle cell anaemia (SS) and the other has sickle cell trait (AS), there is a $50 \%$ chance of a child's having sickle cell disease (SS) and a 50\% chance of a child's having sickle cell trait (AS). 2. When both parents have sickle cell trait (AS), they have a $25 \%$ chance of a child's having sickle cell disease (SS).

Causes of symptoms are due to chronic haemolytic anaemia, episodic occurrence of vasoocclusive events. Reduced growth and development of these affected children, autospleenectomy, recurrent leg ulcers, avascular necrosis, hand foot syndrome, prone to acute infections especially pneumonia and meningitis, jaundice, pigment gall stones, acute abdominal pain, priapism, salmon patches, acute chest syndrome. Four types of crises are encountered in sickling syndromes 1. Sickling crisis(vasoocclusive crisis) 2.hemolytic crisis,3. Aplastic crisis 4. Sequestration crisis. ${ }^{(8)}$

The actual anaemia of the illness is caused by haemolysis, the destruction of the red cells inside the spleen, because of their abnormal shape. The bone marrow attempt to recover by forming new red cells, which does not compensate the rate of destruction. Healthy red blood cells typically live 90 - 120 days, but sickle cells survive 10-20 days. ${ }^{(4)}$ Peripheral smear show moderate to severe degree of anisopoikilocytosis, normocytic normochromic to microcytic hypochromic red cells, sickle cells, boat shaped cells, ovalocytes, nucleated red cells, polychromatophilia and target cells, howell-jolly bodies, reticulocytosis. ${ }^{(9)}$

Improved knowledge of geographical distribution of sickle cell anemia is essential for public health policies. It is better for assessment of requirement for healthcare infrastructures, screening programmes and treatment for prevention and management of sickle cell anemia. ${ }^{(10)}$ 
The goal of this study is to highlight the lack of knowledge and awareness of sickle cell disease among sickle cell disease patients. This study was planned to know the epidemiology of sickle cell anemia and its interventions.

\section{Materials and Methods}

This study period was conducted in the Department of Pathology of district hospital, Khandwa. Data were collected over 3-months period between 1 January 2019 to 31 March 2019. Inclusion criteria: All patients who diagnosed or suspecting to have sickle cell hemoglobinopathies which is confirmed by sickling test.

Blood sample was collected in EDTA bottles for determination of haemoglobin and HB electrophoresis. Haematological analyses were carried out using 3 parts Automated Haematology Analyzer. The study included all cases of anaemia having haemoglobin less than $12 \mathrm{gm} / \mathrm{dl}$. Grading of anaemia-The patients were then grouped as mild (10-10.9 gm \%), moderate (7-9.9 gm \%) and severe $(<7 \mathrm{gm} \%)$ anaemia based on their initial haemoglobin level. Leishman stained smears of PBS were examined. Sickling of the red blood cells on a blood film can be induced by sodium metabisulfite. Sickle cell slide test: when red cells containing $\mathrm{HbS}$ are deprived of oxygen, they become sickle shaped. Reduced agent that is used to remove oxygen from red cells is $2 \%$ sodium metabisulphite. ${ }^{(11)}$

Small quantity of blood hemolysate from each subjects was placed on the cellulose acetate membrane and carefully introduced into the electrophoretic tank containing Tris-EDTA borate buffer at PH 8.9. The electrophoresis was allowed to run for 15 minutes at $160 \mathrm{~V}$. Haemolysates from blood samples of known genotypes ( $\mathrm{Hb} \mathrm{A}, \mathrm{HbA} 2$ and $\mathrm{Hb} \mathrm{F}, \mathrm{HbS}$ ) were run as reference standards. The results were read according to the migration pattern of the haemoglobin variant ${ }^{(7)}$. Patients were recorded in proforma, including detailed history, clinical profile, haematological parameters, sickling test and HB electrophoresis.

\section{Results}

Prevalence of SCD in this area is $8.57 \%$. Incidence in tribal is $67 \%$.Patient ages ranged from 2 to 15 years (mean10.8 years) at the time of recruitment. 8 patients $(53.33 \%)$ were male. 9out of 15 patients $(60 \%)$ had clinically detectable splenomegaly and 4 (26.66\%) had hepatomegaly. The peak prevalence for both occurred in the 5-10 year age group where $33.33 \%$ of patients had splenomegaly and $13.33 \%$ had hepatomegaly. Maximum no. of cases present with symptoms of pallor (100\%) followed by fever (33.33\%), abdominal pain (26.66\%), chest and joint pain (20 $\%) \&$ cough \& difficulty in breathing (20\%) and skin infection $(6.66 \%)$ were found in sickle cell patients. Laboratory parameters showed a hemolytic profile. Mean haemoglobin $9.4 \mathrm{gm} / \mathrm{dl}$, Mean RBC count 4.17, Mean HCT31.33, Mean MCV 75.52, Mean MCH 23.3, Mean MCHC 32, Mean RDW 19.11, Mean, Mean platelet count 3.22, WBC Count 8860 cells/cumm.

Table 1 The demographic characteristic of patients according gender

\begin{tabular}{|c|c|c|c|c|}
\hline Age Group & Male & Female & Total & Percentage \\
\hline Years & $\mathrm{N}$ & $\mathrm{N}$ & $\mathrm{N}$ & $\%$ \\
\hline $0-5$ & 1 & 1 & 2 & 13.33 \\
\hline $6-10$ & 3 & 2 & 5 & 33.33 \\
\hline $11-15$ & 4 & 4 & 8 & 53.33 \\
\hline Total & $\mathbf{8}$ & $\mathbf{7}$ & $\mathbf{1 5}$ & $\mathbf{1 0 0}$ \\
\hline
\end{tabular}

Maximum number of cases $(53.33 \%)$ were found in 11-15 years of age group (Age range: upto 15 years) with male predominance.

Table 2 Frequency of SCH with respect to gender

\begin{tabular}{|l|c|c|c|}
\hline Gender & \multicolumn{2}{|c|}{$\begin{array}{c}\text { Type of SCH } \\
(\%)\end{array}$} & Total \\
\hline & SCA & SCT & \\
\hline Male & $5(33.33 \%)$ & $3(15 \%)$ & $8(53.33 \%)$ \\
\hline Female & $2(13.33 \%)$ & $5(33.33 \%)$ & $7(46.66 \%)$ \\
\hline Total & 7 & 8 & $15(100 \%)$ \\
\hline
\end{tabular}

Table 3 Distribution of Clinical symptoms and signs in study subjects

\begin{tabular}{|l|c|c|}
\hline Clinical Features & N & Percentage \% \\
\hline Pallor & 15 & 100 \\
\hline Fever & 5 & 33.33 \\
\hline Abdominal Pain & 4 & 26.66 \\
\hline Chest pain \& joint pain & 2 & 13.33 \\
\hline Cough, difficulty in breathing & 3 & 20 \\
\hline Skin infections & 1 & 6.66 \\
\hline Vascular occlusive crisis & 3 & 20 \\
\hline Hemolytic crisis & 2 & 13.33 \\
\hline
\end{tabular}


Maximum no. of cases present with symptoms of pallor (100\%) followed by fever (33.33\%), abdominal pain $(26.66 \%)$, chest and joint pain (20 $\%) \&$ cough \& difficulty in breathing (20\%) and skin infection $(6.66 \%)$ were found in sickle cell patients..

Table 4. Radiological findings in study subjects

\begin{tabular}{|l|c|c|}
\hline Radiological Findings & N & Percentage \\
\hline Splenomegaly & 9 & $60 \%$ \\
\hline Hepatomegaly & 4 & $26.66 \%$ \\
\hline
\end{tabular}

In our study, cases of splenomegaly were $60 \%$ and cases of hepatomegaly were $26.66 \%$.

Table 5 Distribution of study subject according to severity of Anaemia

\begin{tabular}{|l|c|c|}
\hline Hemoglobin Level & Total & $\mathbf{\%}$ \\
\hline 7 gm\% & 1 & 6.66 \\
\hline $7-9.9$ gm\% & 6 & 40 \\
\hline$>10$ gm\% & 8 & 53.33 \\
\hline Total & $\mathbf{1 5}$ & $\mathbf{1 0 0}$ \\
\hline
\end{tabular}

Severe anaemia $6.66 \%$, moderate anaemia $40 \%$ and mild anaemia $53.33 \%$ with male predominance.

Table 6 Haematological parameters in SCD children

\begin{tabular}{|l|c|c|}
\hline Parameters & Range & Mean \\
\hline $\mathrm{Hb}$ & $4.9-12.0$ & 9.43 \\
\hline RBC & $1.57-5.88$ & 4.17 \\
\hline $\mathrm{HCT}$ & $14-39.4$ & 31.33 \\
\hline $\mathrm{MCV}$ & $64.6-99.6$ & 75.52 \\
\hline $\mathrm{MCH}$ & $19.7-31.2$ & 23.3 \\
\hline MCHC & $28.3-36.6$ & 32 \\
\hline RDW & $12.5-46.6$ & 19.11 \\
\hline WBC Count & $3800-17300$ & 8860 \\
\hline
\end{tabular}

\section{Discussions}

Our study involved children with sickle cell anemia were less than 15 years of age and diagnosis is confirmed by haemoglobin electrophoresis.

The prevalence of Sickle cell anaemia in this area is $8.57 \%$ which is similar to the study of Stephen $\mathrm{N}$ et $\mathrm{al}^{(1)}$ reported $2.69 \%$ and Kamble et $\mathrm{al}^{(12)}$ reported $5.7 \%$

Incidence was maximum in schedule cast and tribes $67 \%$ which was similar to Stephen $\mathrm{N}$ et al ${ }^{(1)}$ and Kamble et al ${ }^{(12)}$ reported $70 \%$.

Our sample size was 175 patients with median age of patients is 6 years ranged from 2-14 years which is similar to study of Manish et $\mathrm{al}^{(13)}$ reported median age of patients is 6.3 years ranged from 0.8 to 13.7 years. ${ }^{(13)}$ The age at first diagnosis of SCD was 2 years in our study. Majority of patients aged between 11-15 years of age. Milena Magalhães Aleluia ${ }^{(14)}$ and Manish et $\mathrm{al}^{(13)}$ et al reported first case in younger than 6 months of age. Majority of patients were aged between 6 and 10 years. ${ }^{(14)}$

The gender ratioof the SCD patients were male $53.33 \%$ and female $46.66 \%$.Mohieldin Elsayid et $\mathrm{al}^{(16)}$ reported $58 \%$ males and $42 \%$ females with $\mathrm{SCH}$. Manish et al ${ }^{(13)}$ reported $55 \%$ were male and $45 \%$ female. In our study male:female ratio was $1.14: 1$ which is similar to the study of Stephen et $\mathrm{al}^{(1)}$ reported 1:1 and Kamble et $\mathrm{al}^{(12)}$ reported 1.65:1.

SCA is frequent in males than females patients with SCH. The SCA was highly frequent (33.33\%) among males while among the females the incidence was $13.33 \%$ out of all patients with $\mathrm{SCH}$ which is similar to the study of Mohieldin Elsayid et $\mathrm{al}^{(15)}$ reported SCA was frequent (56.4\%) among males while among the females the incidence was $40.5 \%$ out of all patients with $\mathrm{SCH} .{ }^{(15)}$

Pallor was recorded in $100 \%$ and fever in $33.33 \%$, abdominal pain (26.66\%), chest and joint pain $(20 \%) \&$ cough \& difficulty in breathing (20 $\%)$ and skin infection (6.66\%) were found in sickle cell patients. Manish et al ${ }^{(13)}$ reported fever was recorded $12 \%$, hypoxaemia $6 \%$, bone and joint abnormalities, including swelling and tenderness $4 \%$.Vascular occlusive crisis $20 \%$ was the commonest crisis encountered followed by hemolytic crisis $13.33 \%$ which is similar to the study of kamble study ${ }^{(12)}$ et al reported vascular occlusive crisis $23.3 \%$ and haemolytic crisis 16.3\%. Milena Magalhães Aleluia ${ }^{(14)}$ et al also reported hemolytic profile. The commonest precipitating factor for painful crisis is cold, education and proper clothing may minimize its effect. $^{(4)}$

9 of 15 patients $60 \%$ had clinically detectable splenomegaly and $26.66 \%$ had hepatomegaly. The peak prevalence for both occurred in the 5-10 year 
age group which is similar to Milena Magalhães Aleluia et al ${ }^{(14)}$ reported spleenomegalywere $44 \%$ of patients and $30 \%$ had hepatomegaly. Manish et $\mathrm{al}^{(13)}$ reported $33 \%$ had clinically detectable splenomegaly and $20 \%$ had hepatomegaly.

In our study the mean haemoglobin concentration was $9.4 \mathrm{gm} / \mathrm{dl}$, mean HCT $31.33 \%$, mean MCHC$32 \mathrm{~g} / \mathrm{dl}$, mean MCV- 75.52fl, which was similar to the study of Manish Sadarangani et al ${ }^{(13)}$ reported in $7.3 \mathrm{gm} / \mathrm{dl}$, mean HCT $23.1 \%$, mean MCHC$31.8 \mathrm{~g} / \mathrm{dl}$, mean MCV-83.8 fl.

Morphological findings: Peripheral smear showed microcytic hypochromic to normocytic normochromic picture with sickle cells, nucleated red cells, schistocytes, Howell jolly bodies, which was seen in all cases. The sickling test by sodium metabisulphite showed all the patients to be positive. Mohieldin Elsayid et al ${ }^{(15)}$ reported same results.

$\mathrm{Hb}$ electrophoresis revealed the incidence of 46.66 $\%, 53.33 \%$ of the patients suffered from SCA, SCT respectively. Mohieldin Elsayid et al reported $96.7 \%, 3.3 \%$ of the patients from SCA, $\mathrm{SCT}$, respectively. ${ }^{(15)}$ The percentage of $\mathrm{HbS}$ is greater than percentage of $\mathrm{HbA}$, individuals with two copies of HbS develop sickle cell disease that show 90 to $95 \% \mathrm{HbS}$, no $\mathrm{HbA}$, and slightly elevated $\mathrm{HbF}$ in 5 to $10 \%$ range.

The success of premarital screening programmes is depending on adequate religious support, government policy, education and counselling. This study is attempts to awareness of clinical manifestations, treatments, and genetic counselling methods for sickle cell disease.

Affected individuals who are suspected should be screened for evaluation of risks, education, and assessment of growth and development. ${ }^{(6)}$ Mental health screening for signs of depression, anxiety, and isolation should occur. ${ }^{(6)}$ The clinical diversity of SCD includes hemolytic and vaso-occlusive episodes, infections, stroke, acute chest syndrome, pulmonary hypertension, multiple organ dysfunctions. The use of medication, prophylactic vaccines and practicing healthy habits are recommended. ${ }^{(14)}$
Environmental controls include avoiding dehydration, extremes temperature, physical exhaustion, high altitude without oxygen supplementation. ${ }^{(6)}$

\section{Conclusion}

SCD is prevalent in this area. Evaluation of Relatives at Risk for the purpose of early diagnosis and treatment. Families should appreciate the importance of routine health maintenance visits, prophylactic medications and early intervention for complications. Proper and adequate counselling should be given to couple before marriage and haemoglobin genetic counselling and education should be included.

\section{References}

1. Stephen N, Nden N, Gusen NJ, Kumzhi PR, Gaknung B, Auta DA,Bulndi LB, Mbursa C, Kumari VP, Nanvyat N. Prevalence of sickle cell disease among children attending plateau specialist hospital, Jos, Nigeria, Acta Med Int 2018;5:20

2. Graham R. Serjeant1,* Kanjaksha Ghosh,2 and Jyotish Patel3 Sickle cell disease in India: A perspective. Indian Journal of Medical Research. 2016 Jan; 143(1): 2124.

3. CASSIE JESSICA OSBOURNE, SICKLE CELL DISEASE AWARENESS AMONGST COLLEGE STUDENTS, Urbana, Illinois, University of Illinois at Urbana-Champaign, 2011

4. Obeagu, Emmanuel if eanyl1, Ochei, K.C.2, Nwachukwu, B.N.3, Nchuma, Blessing Ogechi4, Sickle Cell Anemia: A Review, Scholars Journal of Applied Medical Science, 2015; 3(6B): 2244-2252

5. Vinay kumar, Abdul k.Abbas, Jon C.Aster, Robbins and Cotran, Pathologic basis of Disease, South asia edition. 2015. ISBN978-1-4557- 2613-4 Volume 1 page no. 635. 
6. MA Bender, MD, PhD. Sickle Cell Disease. Gene Reviews Advanced Search, August 17, 2017.

7. Eman A. Ajjack1, Hiba A. Awooda2, Sana Eltahir Abdalla3, Haemoglobin Patterns in Patients with Sickle Cell Haemoglobinopathies, International Journal of Hematological Disorders, 2014, Vol. 1, No. 1, 8-11

8. Dr.Tejindarsingh MD, FICP, FISHTM, Atlas and text of Hematology, Department of Pathology, Maulana Azad Medical College, New Delhi. 2014. Fourth edition. ISBN-978-81-7739-413-9. Chapter 4 Page no. 173 .

9. Barbara J. Bain, Imelda Bates, Mike A. Laffan, S. Mitchell Lewis, Dacie and Lewis, Practical Haematology, 2014. Eleventh edition. Chapter 5, page no. 84

10. CarinnaHockham, Samir Bhatt, Roshan colah, Malay B. Mukharjee, Bridget S. Penman, Sunetra Gupta, Frederic B. Piel, The spatial epidemiology of sickle cell anaemia in India. Sci Rep. 2018;8: 17685.

11. Shirish M Kawthalkar, essentials of Clinical Pathology, First edition, Chapter 27 Laboratory tests in Anemia, Page no. 266

12. Kamble M, Chaturvedi P., Epidemiology of sickle cell disease in a rural hospital of central india, Department of Pediatrics, Mahatma Gandhi Institute of Medical Science, Sewagram, Wardha, Maharashtra. Indian Pediatr.2000 Apr;37(4):391-6

13. Manish Sadarangani,1 Julie Makani,1,2,4 Albert N Komba,1 Tolu Ajala-Agbo,3 Charles R Newton,1 Kevin Marsh,1,4 and Thomas N Williams. An observational study of children with sickle cell disease in Kilifi, Kenya. British Journal of Haematology. 2009 Sep; 146(6): 675-682.
14. Milena Magalhães Aleluia,1,2 Teresa Cristina Cardoso Fonseca,3,4 Regiana Quinto Souza,3,4 Fábia Idalina Neves,3 Caroline Conceição da Guarda,1,2 Rayra Pereira Santiago,1,2 Bruna Laís Almeida Cunha,2 Camylla Villas Boas Figueiredo,1,2 Sânzio Silva Santana,1,2 Silvana Sousa da Paz,1 Júnia Raquel Dutra Ferreira,1,2 Bruno Antônio Veloso Cerqueira,5 and Marilda de Souza Gonçalves corresponding author1,2. Comparative study of sickle cell anemia and hemoglobin SC disease: clinical characterization, laboratory biomarkers and genetic profiles. BMC Hematology. Sep 15. 2017;

15. Mohieldin Elsayid,1 Mohammed Jahman Al-Shehri,1 Yasser Abdullah Alkulaibi,1 Abdullah Alanazi,2 and Shoeb Qureshi3 Frequency distribution of sickle cell anemia, sickle cell trait and sickle/betathalassemia among anemic patients in Saudi Arabia. Journal of Natural Science Biology and Medicine. 2015 Aug; 6(Suppl 1): S85-S88. 